\title{
Teacher training in France in the early 2010s
}

Guy Lapostolle $\mathrm{e}^{\mathrm{a}}$ and Thierry Chevaillier ${ }^{\mathrm{b}}$

${ }^{a}$ Institut Universitaire de Formation des Maîtres de Bourgogne, Dijon, France;

${ }^{\mathrm{b}}$ University of Burgundy, France

Journal of Education for Teaching, Vol. 37, No. 4, November 2011, 451- 459

The organisation of teacher training was thoroughly transformed in France in 2010. This transformation was the consequence of three interrelated reforms: the requirement of a Master's degree for all teachers, the new recruitment process for teachers and the integration of teacher training colleges (IUFM) into the universities. Universities are now responsible for providing initial training in programmes leading to a Master's degree. The state school system then recruits graduates through a competitive examination and newly recruited teachers are offered 'deferred initial training', the exact content and duration of which have not yet been fully specified. By looking at the former conditions of training and at the new organisation, it is, however, possible to outline the content and purpose of this further training.

Keywords: teacher education; degree requirement; universities; curriculum; recruitment; in-service training

\section{Introduction}

The year 2010 marks a thorough transformation of the organisation of teacher training in France. Teachers in the public sector are now to be recruited after graduating from Master's programmes organised by universities. Distinguishing between training and recruitment is a radical change since the two process were previously integrated, with the Ministry of Education being simultaneously in charge of recruitment and professional training.

A peculiar feature of the French education system is that teachers in the public sector are state civil servants and, as such, are recruited by a unique employer, the National Education Ministry. Until 2010, the Ministry used to select graduates with Bachelor's degrees and prepare them for two years in institutions that were distinct from universities, the Instituts Universitaires de Formation des Maîtres (IUFM). The first year was dedicated to preparation for the competitive recruitment examinations and the second year was devoted to professional training. This preparation did not lead to a degree and, therefore, students who attended this preparation cycle but were not recruited in the end had no academic recognition for the two years they had studied after their 


\section{Bachelor's degree.}

The principle of this competitive recruitment was to choose the best candidates out of a wide pool of applicants. Each year, a number of positions are open for each category of teachers and a series of examinations, both written and oral, allows the Ministry to select candidates who are then appointed as civil servants with a probationary period of one year. During this year, professional training of teachers used to take place in IUFM. At the end of this probationary period, teachers were granted life tenure and posted to a school.

The new organisation means that students simultaneously study for a degree and prepare for the recruitment examination. It was conceived as a way to improve teacher training, on the basis of recommendations made in 2001 by the Universities' National Evaluation Committee (CNE) in a report advocating a firmer grounding of teacher training in both research and field training. Nevertheless, it creates a new range of problems and distortions that need being uncovered and analysed.

This paper will first describe these reforms and their implementation, then identify their effects, on the basis of data currently available and, finally, attempt a causal explanation of the malfunctions of the new organisation.

\section{The impact of the three reforms on the institutions involved in teacher training}

The transformation of training and recruitment of teachers results from distinct reforms conceming three interrelated aspects of the organisation of teacher training: the setting of the entrance requirement to the profession at the level of a university Master's degree ("Masterisation" of teacher training), the change in the recruitment process, and the integration of teacher training colleges (IUFM) into the universities.

The first two reforms led to recruiting teachers with a Master's degree through a competitive examination (concours) organised at the regional level (Académie) for primary school teachers and at the national level for secondary school teachers, subject by subject, during the second year of the Master's programme. Before 2010, the only requirement for taking the recruitment examination was a Bachelor's degree. Students could apply straight for the examination but a majority prepared for it in two-year training colleges where they acquired both academic and professional education during the first year, at the end of which they sat the competitive examination. Those who passed were appointed as civil servants for a one-year probationary period; they spent a second year in the college with professional training that included field experience in the shape of placements in schools for six to eight hours a week. If their training was deemed adequate, they were given life tenure and posted to a school where they had a full teaching load of 1526 hours a week, according to school level and qualification. During the first 
two years in their new school, they were entitled to specific in-service induction training periods (four weeks in the first year and two weeks in the second year) and they were assigned a mentor (référent).

To sum up the previous organisation, in the first year in the teacher training college, students, since they had no need to study for a further degree, were able to prepare full time for the recruitment examination. During the second year, they alternated between training in the college and placement in schools, where they were given full responsibility in a classroom under the guidance of a tutor. In the two years of permanent employment in a school, the newly appointed teachers could benefit from the guidance of a mentor and from training periods in the college.

From 2010 onwards, students contemplating a teaching career apply to the competitive recruitment examination after graduating from university with a Master's degree or, at !east, if they were enrolled in the second year of a Master's programme, provided they were awarded their Master's degree in time for their appointment.

As Xavier Darcos, then Education Minister, explained (Darcos 2008), it was legitimate to recognise the two years students had to spend studying after their Bachelor's degree in order to become a qualified teacher with a Master's degree. This decision was in line with the trend observed in other European countries following the inception of the Bologna process. This upgrading had also been set as a policy objective by the 2005 Act on the Future of Education and as a target for the Ministry of Education by the French President Sarkozy in 2007.

The immediate effect of the first two reforms has been that prospective teachers have to prepare for a Master's degree and a recruitment examination at the same time. The timing of the recruitment examination during the second year of the Master's programme collides with that of the Master's programme. The written part of the examination is organised at the beginning of the first semester of the second year and the oral part towards the end of the second semester. Since students who do not pass the written part are eliminated from the competition, universities must provide specific courses for those who would drop the preparation and reorient themselves towards a different Master's programme in the second semester. Preparing students for the written part of the examination also implies that universities should organise specific courses that may not be relevant to the curriculum of an academic Master's.

The third reform was part of the 2005 Act (MEN 2005) that transferred the independent IUFMs to the universities, turning them into 'internal schools' with limited administrative autonomy. Since universities are autonomous corporations, as opposed to former IUFM that were largely controlled by the National Education Administration (university presidents, elected by the board of directors of their university, are formally independent from the government, whereas IUFMs used to be administered by a director appointed by the 
Minister and a board chaired by the regional head of the National Education Administration, the recteur d'Académie), this transfer entails a separation of initial and induction training. The universities are in charge of initial training of the students, then the Education Ministry hires them and is responsible for inservice training. As a result of a decentralisation of the state administration, the regional heads of the National Education Administration have been given a degree of autonomy for organising education, especially management of staff, including allocation, mobility and training. This introduces variety in the way such training is conducted across the country. In each of the regions, the universities and their teacher training schools negotiate with the local head of the education administration on the conditions of placements in schools for students enrolled in Master's programmes and for the in-service training of new teachers.

It can be seen, therefore, that by contrast with the previous situation, in which IUFMs dealt with both initial and in-service training, there is now a clear division of responsibilities between universities as training agencies and the Ministry as the employer of the teachers.

Consequences of the combined reforms on the conditions of teacher training, the sudden implementation of the reforms in 2010 was perceived as highly disruptive. After a few adjustments, the new organisation stabilised so that it is now possible to assess it and identify its main merits and limitations.

From the students' point of view, a strong feature of this new setting is the introduction of initiation to research in the curriculum. Students preparing to become teachers in secondary education are now confronted during their studies with research in their specific subjects, as they are educated in the relevant department of universities. Prospective primary school teachers, enrolled in cross-disciplinary Master's programmes generally managed by the new education colleges (the former IUFMs), also receive an introduction to research in the various subjects they will have to teach, with a focus on didactics, psychology and education. This is considered an improvement as it allows future teachers to reflect on their subject and on their practice and to realise better the evolution of the contents taught in a lifelong learning perspective. Familiarity with research that emerged as an essential dimension of the teaching profession appears now as a feasible objective.

The new organisation, however, faces a challenge in that the Master's programmes now pursue three goals (research training, professional training and preparation for recruitment competitive examinations) that are potentially conflicting. Research training implies mastery of methods of investigation and a critical stand towards knowledge and the way it is developed. Professional training ought to equip future teachers with a solid command of stable contents 
and techniques to use in the classroom. Preparation for recruitment is highly dependent on the expected knowledge on which the examination will test and rank students, as specified in the detailed regulations of the recruitment process. It is likely, at least in the near future, that these aims will not align spontaneously. The reliance on a specific examination of the candidate's knowledge of their subject in the recruitment process shows that universities are not trusted by the education administration in assessing their graduates. There may be disagreement about the weight of the professional elements in the recruitment examination as compared to the academic elements. The requirement that prospective teachers should be enrolled in 'ordinary' Master's programmes that were previously designed to prepare students for doctoral programmes may be seen as a threat to the quality of such programmes, especially if the preparation for the recruitment examination and school placements, that are an essential part of the professional training, take place in the precise period where students' research used to be organised.

These contradictions seem to concern far less the training of teachers for primary education for two reasons: in most cases, new Master's programmes were created by the schools of education or, at least, with their participation. In primary school recruitment examinations, there is traditionally much less tension between professional and academic content. All actors involved in the training of primary school teachers welcome the introduction of research training since it is seen as raising the level of training that, until the early 1990s, was organised without any relationship to universities (Lapostolle, Mabilon-Bonfils, and Genelot 2009).

This is not the case for secondary school teachers' training, where a faculty in charge of Master's programmes see the inclusion of professional training in the curriculum as a threat to the quality of their programme. A solution that has been widely adopted is to transfer research training to the first year of the Master's programme in order to make room in the second year for professional training.

The issue of the professional training of teachers is more problematic since there is no requirement for candidates for recruitment examinations to have attended professional training courses. A graduate from any Master's degree can apply and take part in the recruitment process. Since the proportion of this process devoted to testing professional knowledge and skills is much smaller than that of the academic part, it is possible that a student could be recruited without any knowledge or experience of what the teaching profession is about.

To allow students enrolled in Master's programmes to acquire a real experience of the profession, field activities are included in the curriculum, especially in the shape of placements in schools (MESR 2007). For such placements, the universities depend on the employer of acting teachers, i.e. the 
head of the regional administration of the National Education Ministry, the recteur d'académie. The Ministry has instructed recteurs to provide universities with placements for students enrolled in Master's preparing for the teaching profession (MEN 2010a). Two types of placements are organised:

- Work shadowing or accompanied practice (stage d'observation ou de pratique accompagnée) in which the student is in the position of observer in the classroom or takes part in teaching with the help and in the presence of the teacher. Such placements are offered to first or second year Master's students and last for up to six weeks altogether over the year.

- Placement with full responsibility for a classroom (stage en responsabilité). Such a placement is limited to second year students. It lasts for six weeks or 108 hours. The student receives financial compensation and a mentor selected among the teachers of the school is assigned to the student with the task of advising, guiding and supervising him/her in the school during the whole of the placement period. In accordance with the common regulations of university placements, the teaching staff of the Master's programme is responsible for the organisation and assessment of this field work. In the school of education, specialised support is also organised for students during the placement. A contract is signed between the university and the regional administration of education. There is no formal direct link between the school of education and the mentor or the head of the school, which may hinder co-ordination between fieldwork and training courses.

The organisation of such placements is further constrained by the fact that these students are used to replace new teachers who are on leave to attend compulsory in-service training sessions during their first two years of appointment. Either one or two students on placement take charge of the classroom during this training leave. This scheme, however, may not provide enough places for the students enrolled in the Master's programmes and they are sometimes allocated only to students who have passed the written part of the recruitment examination. Such a situation is detrimental to the students who have not been able to find a placement and therefore do not meet the requirements of the programme and fail.

Those who pass the recruitment examination are appointed as civil servants on a probationary period of one year, after which they are given life tenure if they have been deemed to be satisfactory in their teaching. From the first day of the school year, they are responsible for their class on a full-time basis, with the 
exception of some time devoted to in-service training.

\section{In-service 'initial deferred training'}

A ministerial instruction to the regional administrators of education (MEN 2010b) provides for the organisation of in-service training for graduates during their first two years as permanent teachers. During the first year the induction scheme comprises three steps: first, a period of welcome and integration into the school; second, support by a mentoring colleague mixing classroom practice and analysis of situations; and third, one or several periods of continuous training organised by universities or other qualified institutions. It is expressly stated that these activities are under the responsibility of the state as employer. The overall duration of these training activities is set to one-third of the yearly teaching load of the new teacher, that is 12 weeks out of 36, a much longer period than anticipated but a concession made by the Ministry to the teachers' unions to ease the negotiations.

As seen earlier, during the in-service training sessions in the first year, new teachers are replaced by second year Master's students on 'full responsibility placement'. As a result, in-service training sessions take place late in the school year since student placements are usually planned during the second semester. This is not in phase with the needs of the new teachers, who meet most of the problems that training is supposed to help solve during the first few months of practice. In a few regions, this gap has been dealt with by the use of video or online training programmes providing advice and tips to beginners who are struggling after their first contact with their pupils. The National Institute for Pedagogy Research (INRP) had anticipated this problem and produced a very effective set of online resources for the newly recruited teachers, called 'neopass'.

Since the sum of the various in-service training activities offered to the new teachers is 12 weeks, the heads of schools have a very hard time providing for replacement of teachers on training leave. One of the solutions, as we have just seen, is to resort to education students on placement in the school. Others include supply teachers, either permanently employed or on temporary contracts, but it is likely that regional administrations of education will have neither the financial resources nor the personnel for this to happen. The new teachers, already overwhelmed with the preparation for their teaching, will be offered this in-service training in very problematic conditions. It will be difficult to keep this requirement of 12 weeks of training without additional resources and it is likely to be downsized in the future. Indeed, in the current school year (2010/11), according to information provided by the teachers' unions (SNUipp, 2010; SGEN-CFDT, 2010), only part of the four weeks of continued training that was prescribed for newly appointed teachers will be 
provided in accordance with the 'terms of reference of teacher training' (MEN 2006). In following years, the scheme for 'deferred initial training', designed to complement professional training acquired before graduation, is likely to be limited to the mentoring part, through which experienced colleagues will transmit their tricks and routines to the new teachers.

To sum up the impact of these reforms of teacher training, the most positive feature is the introduction of research. The expectations for an efficient training of teachers based on a combination of theory and practice and on a balance between fieldwork and coursework may not be reached entirely, especially for in-service continued training that may amount to no more than mentoring.

\section{Areas of concern}

Several factors may explain the likely malfunctions of the new organisation of teacher training. The first factor is the attempt to bring a personnel management solution to a pedagogical problem: budget cuts, triggered by excessive public debt, affect both the initial training of teachers and the continued training of newly recruited teachers, by linking the placement of the former to the induction sessions of the latter. Employing students full time in the classroom during their placement is detrimental to proper training since it inhibits a time balance between practice and reflection on practice. Resorting to using students on placement to replace new teachers on training leave prevents the provision of appropriate training that will focus on the needs of teachers. Regional administrators, facing reduced training budgets, often give priority to placement of students over continued training of newly recruited teachers, thus jeopardising a phase considered as essential in the building of an efficient teaching profession.

A second factor is the new 'division of labour' between the state as employer and the universities as training providers. Despite the signing of agreements between them at the regional level, the initial principle stated by Education Minister (Darcos 2009) remains a guideline for the teachers' training policy that considers that mentoring is the most effective tool for training teachers:

Today, future teachers take an exam and enter training colleges where they study general theory about education. From time to time, they are sent to a school to replace teachers on leave. This is not a proper way of training professionals. To say it in different words, they are constantly using a flight simulator. A flight simulator is not adequate to train pilots. Trainees should sit in the cockpit with a co-pilot and start flying: This is what I propose.

The ministerial belief that mentoring should make up the larger part of teacher training is archaic but nevertheless shared by a majority of the public. 
Research on teacher training has repeatedly shown that, although mentoring is useful to acquire the 'tricks of the trade', it does not prepare professionals to adapt instantly to changing situations in their everyday practice or for future evolutions in teaching that they will face during their career. This position of the education minister and the resulting organisational choice of separating training in universities from in service training provided mainly through mentoring is an illustration of the precedence of ideology over the results of scientific research that prevails in French education policy (Lapostolle)

A third factor lies in the recruitment process that operates in France for teachers as well as for all public agents, the centralised competitive examination (concours de recrutement). Such examinations need specific preparation that is both long and difficult. In the training of future teachers, this preparation takes a lot of time that would be better devoted to an introduction to research and professional training. The founding principles of the French Republic require that teachers must be trained and recruited in exactly the same conditions over the whole of the national territory. Plans to abolish national competitive examinations and to transfer the recruitment responsibility to heads of schools, as is done in many European countries, have met fierce opposition from the teachers' unions, on the basis that it would jeopardise the principle of equality in provision of public service over the national territory and that it would subject teachers to the 'arbitrary power' of school heads. This position is endorsed by a substantial part of the population and the political establishment.

As the conditions of teacher training may vary from region to region in the new organisation, they hold that the only way of enforcing 'republican' principles is to maintain a nationally centralised recruitment process. The fact that such a process, in itself does not ensure that teachers will have acquired the necessary skills is overlooked and accepted for the sake of principles.

A fourth factor may be the haste with which the reforms were enacted and implemented. This was partly justified by the need to comply with a common European framework. Setting a Master's degree as a requirement for the teaching profession appears beneficial in terms of social recognition as well as for the improvement of professional skills, like the introduction of the research element in the curriculum. It seems, however, that such an evolution of the curriculum is not compatible with keeping unchanged the recruitment process. In order for the benefits of the reform to be reaped, the organisation and content of the recruitment examinations need to be altered.

Without anticipation of the necessary adaptation of the training system, the compliance with EU or the Bologna recommendation is seen as a political device used to overcome national resistance to change. There is a suspicion by part of the public that changes in longstanding features such as 
competitive recruitment processes based on national examinations or centralised uniform administration of education are a way to implement liberal policies aiming at handing over decision making to the 'market'. The few attempts at introducing quasi-market devices such as parents' choice of schools for their children are closely scrutinised by researchers who try to check whether they increase inequality in education outcomes (Meuret, Broccolichi, and Duru-Bellat 2001).

To sum up, there are several compounding explanations for the present malfunctioning of teacher training: incompatibility between the two logics at work, personnel management and curriculum design; a precedence of ideology over science-based evidence in public policy making, and a hasty implementation of reforms without proper preparation.

\section{Conclusion}

The three distinct reforms of 'masterisation' of teacher training, the recruitment and induction process and the integration of teacher training colleges in universities, have together contributed to the present change in the landscape of teacher training in France. A potentially positive feature is the introduction of research in the education of future teachers. Induction and continued training of newly appointed teachers seem at present to have been sacrificed partly for budgetary reasons. What is lacking most is the implementation of the principle of progressive entrance into the profession, with a combination of 'training by alternance' before recruitment and continued induction training after recruitment.

There is a risk that students will experience a discrepancy between what they learn through placements and through courses. At the same time, they will bear the pressure of preparation for the competitive recruitment examination and that of their placements "with full responsibility" that may not be organised efficiently. Newly recruited teachers will start teaching full time in classrooms with only the assistance of an experienced colleague and will have to wait for several months to resume the formal training necessary to assimilate what they have learned in the classroom. It looks as though, at present, continued training that was to be offered to them in their second year of teaching will not take place or will be drastically reduced because of budget cuts.

Budgetary constraints are likely to become a permanent feature of the education sector. An ideological bias and ignorance of evidence produced by research in shaping education policy also seem to be deeply entrenched. Borrowing policies from abroad and translating European recommendations without the necessary adaptation to national conditions may also become part of the landscape. Nevertheless, there is hope that the new organisation of 
teacher training, through progressive amendment and fine tuning, might succeed in improving the quality of education in France.

\section{References}

CNE. 2001. Les IUFM au tournant de leur première décennie. Panorama et perspectives. [IUFMs at the turn of their first decade: Situation and perspectives.] www.ladocumentationfrancaise.fr/rapports .../index.shtml Darcos, X. 2008. Lettre de Xavier Darcos au président de la CDIUFM [Letter of Xavier Darcos to the chairman of the IUFM directors conference.] (Conférence des directeurs d'Instituts Universitaires de Formation des Maîtres), 21 juin 2008. cdiufm.amue.fr.

Darcos, X. 2009. Les grandes gueules, [Excerpts from a Radio Monte Carlo talk show.] 12 February 2009.

http:/www.rmc.fr/blogs/lcsgrandesgueules.php?post/2009/02/12/La-reformedes-enseignants-ll-n-y-a-aucune-raison-de-la-repousser-Xavier-Darcos Lapostolle, G. 2006. Du bon usage de l'expertise dans les politiques éducatives. [For a proper use of expertise in education policies]. Politiques et Management Public 24: 29-54.

Lapostolle, G., B. Mabilon-Bonfils, and S. Genelot. 2009. Transversal training within secondary teachers' training in the face of current reforms in France. Journal of Education for Teaching 35: 205-24.

Meuret, D., S. Broccolichi, and M. Duru-Bellat. 2001. Autonomie des établissements scolaires: finalités, modalités, effets. [School autonomy: Goals, ways and cffects.] Les Cahiers de l'IREDU, $\mathrm{n}^{\circ} 62$.

Ministère de l'éducation nationale (MEN). 2005. Loi d'orientation et de programme pour l'avenir de l'école. [Programming Act for the future of school.] No. 2005-380 du 23 avril 2005. Journal Officiel de la République Française.

Ministère de l'éducation nationale (MEN). 2006. Arrêté du 19-12-2006. Cahier des charges de la formation des maîtres. [Terms of reference of teacher training.] Journal Officiel de la République Française.

Ministère de l'éducation nationale (MEN). 2010a. Circulaire relative à l'organisation des stages pour les étudiants en master se destinant aux métiers de l'enseignement, [Organisation of placement for students in master's programme preparing for the teaching profession.] No. 2010-102 du 13-7-2010. Journal Officiel de la République Française.

Ministère de l'éducation nationale (MEN). 2010b. Circulaire relative au dispositif d'accueil, d'accompagnement et de formation des enseignants stagiaires des premier et second degrés et des personnels d'éducation stagiaires, [Conditions of inception, mentoring and in-service training of first and second year new teachers.] No. 2010-037 du 25-02-2010. Journal Officiel 
de la République Française.

Ministère de l'Enseignement Supérieur et de la Recherche (MESR). 2007.

Circulaire relative à la mise en place des diplômes nationaux des masters ouverts aux étudiants se destinant aux métiers de l'enseignement, [Implementation of new master's programmes for prospective education personnel.] No. 2009-1037 du 23-12-2009. Journal Officiel de la République Française.

Sarkozy, Nicolas. 2007. Lettre de mission au ministre de l'éducation Xavier Darcos du 5 juillet 2007. [Mission statement of the Education Minister Xavier Darcos of 5 July 2007] www.fcpe 34.org/article.php3.

Sgen-CFDT. 2010. Pétition pour la garantie d'une formation Titulaire première année et seconde année dans l'Ain. [Petition for proper in-service training of first and second year new teachers.] www.sgencfdtlyon.fr/spip.php?article296 (accessed May 2010).

SNUipp. 2010. Pétition pour la garantie d'une formation Titulaire première année et seconde année dans l'Ain. [Petition for proper in-service training of first and second year new teachers.] www.snuipp.fr/spip.php?article531 (accessed April 2010). 